\title{
IS VITAMIN D ASSOCIATED WITH TESTOSTERONE IN BENIGN PROSTATE HYPERPLASIA?
}

\author{
Bogdan Roussev ${ }^{1}$, Daniela Gerova ${ }^{2}$, Petar Kosev ${ }^{3}$, Alexander Hinev³ ${ }^{3}$ Dobrin Svinarov ${ }^{4}$, \\ Bistra Galunska ${ }^{1}$ \\ ${ }^{1}$ Department of Biochemistry, Molecular Medicine and Nutrigenomics, \\ Faculty of Pharmacy, Medical University of Varna \\ ${ }^{2}$ Department of General Medicine and Clinical Laboratory, Faculty of Medicine, \\ Medical University of Varna \\ ${ }^{3}$ Department of Surgery, Faculty of Medicine, Medical University of Varna \\ ${ }^{4}$ Clinical Laboratory \& Clinical Pharmacology, Alexander Hospital, \\ Medical University, Sofia, Bulgaria
}

\begin{abstract}
INTRODUCTION: Benign prostate hyperplasia (BPH) affects about $50 \%$ of the male population between 51-60 years of age and almost $90 \%$ of the males aged 81-90. It is considered that $\mathrm{BPH}$ pathogenesis involves epithelial cells and stromal tissue proliferation inside prostate gland and testosterone is one of the promoting factors of prostate cell growth. Evidences about the antiproliferative effects of vitamin $D$ and the widespread vitamin $D$ deficiency and insufficiency among the Bulgarian population suggest a possible relation between vitamin $\mathrm{D}$ and testosterone in $\mathrm{BPH}$ patients.

AIM: The aim of this paper is to evaluate the vitamin D status and total testosterone (TT) levels in BPH patients and their associations with laboratory parameters such as prostate specific antigen (PSA) for prostate growth.

MATERIALS AND METHODS: A total of 37 male BPH patients (mean age 67.14 \pm 7.77 years) were enrolled in the study. In all patients, BPH was histologically proven. PSA and TT levels were analyzed immunochemically. The circulating form of vitamin D, 25-hydroxyvitamin D (250HD) was assayed by liquid chromatography with mass-spectrometry detection (LC-MS/MS). Other covariates (BMI, age,) were collected by interview at the time of hospitalization. Classical biochemical parameters were assayed by routine spectrophotometric tests. Descriptive statistics, variation and non-parametric correlation analysis were used. The level of significance was set at $\mathbf{p}<0.05$.

\author{
Address for correspondence: \\ Bogdan Roussev \\ Department of Biochemistry, Molecular Medicine and \\ Nutrigenomics \\ Faculty of Pharmacy \\ Medical University of Varna \\ 84 Tsar Osvoboditel Blvd \\ Varna, Bulgaria \\ e-mail: bogdanroussev@gmail.com
}

Phone: +359876675088

Received: September 13, 2016

Accepted: December 27, 2016

RESULTS: The mean level of $250 \mathrm{HD}$ for BPH patients was close to the lower reference limit of $50 \mathrm{nmol} / \mathrm{L}$ recommended by the US Endocrine Society Guideline. The majority of $\mathrm{BPH}$ patients (56.8\%) display 250HD levels above $50 \mathrm{nmol} / \mathrm{L}$, $43.2 \%$ of them were vitamin D deficient $(250 \mathrm{HD}<$ $50 \mathrm{nmol} / \mathrm{L}), 8.1 \%$ - with severe vitamin $\mathrm{D}$ deficiency $(250 \mathrm{HD}<25 \mathrm{nmol} / \mathrm{L})$, and only 6 patients $(16.2 \%)$ had optimal 250HD levels above the limit of 75 $\mathrm{nmol} / \mathrm{L}$. The mean serum TT levels of BPH patients were $10.74 \pm 4.026 \mathrm{nmol} / \mathrm{L}$, close to the lower limit of $10.4 \mathrm{nmol} / \mathrm{L}$ for normal TT, according to the recommendations of the Endocrine Society. A significant seasonal variations were found for $250 \mathrm{HD}$ levels
\end{abstract}


Is Vitamin D Associated with Testosterone in Benign Prostate Hyperplasia?

$(\mathrm{p}<0.05)$ between the cold and warm season. Similar seasonality was not established for TT. Two-thirds of $\mathrm{BPH}$ patients (62.9\%) were with PSA values below the upper limit of the reference interval of $4 \mathrm{ng} / \mathrm{ml}$. Higher $250 \mathrm{HD}$ levels $(59.21 \pm 3.756 \mathrm{nmol} / \mathrm{l}, \mathrm{p}=\mathbf{0 . 0 6})$ were established for the group with PSA below the threshold of $4 \mathrm{ng} / \mathrm{ml}$. A moderate negative correlation (Spearman $r=-0.6707, p<0.01$ ) was found only for the vitamin $D$ deficient group. In case of vitamin D sufficiency, a weak positive trend was detected.

CONCLUSION: Our study indicated vitamin D insufficiency in BPH patients according to the criteria of the Endocrine Society. Strong negative correlation between 250HD and TT levels was found for vitamin D deficient BPH patients. Higher 250HD were associated with lower PSA values indicating a potential favorable effect of 250HD on slackening of BPH.

Keywords: 25-hydroxyvitamin D, benigns prostate hiperplasia, testosterone

\section{INTRODUCTION}

Benign prostate hyperplasia (BPH) is a nonmalignant excessive growth of prostate epithelial and stromal tissue. It leads to increased prostate volume and decreased flow of urine through the urethra (1). The prevalence of $\mathrm{BPH}$ is about $8 \%$ in men during their third decade, 50\% in the fifth decade and 90\% in the ninth decade of life $(1,2,3)$.

There is accumulating evidence suggesting that vitamin $\mathrm{D}$ is involved in the pathogenesis of $\mathrm{BPH}$. It has been shown that prostate epithelial cells express vitamin $\mathrm{D}$ receptor (VDR), mediating the biological actions of vitamin D and the enzyme 1-alpha hydroxylase, forming the active form of vitamin $\mathrm{D}$, calcitriol (3). Calcitriol binds to VDR and stimulates the non-classical effects of vitamin $\mathrm{D}$ responsible for its anti-proliferative and pro-apoptotic actions on prostate cells. It has been demonstrated that calcitriol and its analogs inhibit prostate cell proliferation in vitro and in vivo $(4,5)$. A recent epidemiological study showed a decreased risk of symptomatic BPH in men supplemented with vitamin D (6). Significant inverse association between 25OHD levels and prostate volume in adult men included in an Osteoporotic Fractures study was reported by Haghshneno M. et al (4).

It is well known that androgens play a vital role in prostate growth. The most important androgen is testosterone, which is converted to dihydrotestosterone (DHT) inside prostate gland by the local enzyme 5 - $\alpha$ reductase (7). DHT stimulates glandular epithelial prostate cell growth and is considered as a major hormonal factor for prostate enlargement in late adulthood.
A widely used marker for prostate gland destruction is the prostate specific antigen (PSA). Elevated serum PSA is observed in men with $\mathrm{BPH}$, prostatitis, or prostate cancer (8). The relationship between 25OHD and testosterone levels is not fully understood and the literature data are sparse and controversial. There is evidence of increase in TT levels after vitamin $\mathrm{D}$ supplementation in healthy overweight men (9). Other studies did not find any association between 25OHD and TT in healthy adult men (10) and in healthy male subjects supplemented with vitamin D (11). Our previous study revealed lack of association between $25 \mathrm{OHD}$ and PSA in prostate cancer patients (12).

It is widely accepted that $25 \mathrm{OHD}$ is the best indicator for vitamin D status (13). A matter of debate in the vitamin $\mathrm{D}$ research community is regarded to its reference/target ranges (14). Some authorities indicate that even people without signs or symptoms of pathology are deficient or borderline deficient in vitamin $\mathrm{D}$. There are reports stating that secondary hyperparathyroidism can be corrected with an average $25 \mathrm{OHD}$ serum or plasma level at least $75 \mathrm{nmol} / \mathrm{L}$, and a few laboratories use this value as the lower limit of optimal 25OHD serum and plasma concentrations $(15,16)$. The recommended by the World Health Organization serum/plasma level of 50 $\mathrm{nmol} / \mathrm{L} 25 \mathrm{OHD}$ for vitamin D deficiency is based on a significant increase of adverse health outcomes related to osteoporotic bone fractures. The lack of consensus on 25OHD target ranges results in substantial variation in the reference ranges or target values used in different research studies. 
Bogdan Roussev, Daniela Gerova, Petar Kosev et al.

The seasonal variations in $25 \mathrm{OHD}$ levels are well documented $(17,18)$, while for TT the data are limited and controversial. Similar seasonal variations were reported for both $25 \mathrm{OHD}$ and TT in adult men with cardiovascular diseases $(19,20,21)$. Other authors found nonsignificant, but similar monthly variations in $25 \mathrm{OHD}$ and free testosterone (22).To our knowledge there are no studies examining the causal link between 25OHD and TT levels and their seasonal variations in $\mathrm{BPH}$ patients.

The aim of the present study was to evaluate vitamin D status and TT levels in BPH patients and their associations with laboratory parameters for prostate growth, such as PSA.

\section{MATERIALS AND METHODS Patients}

A total of 37 male BPH patients from 52 to 85 years (mean age 67.14 \pm 7.77 years) were enrolled in the study. The clinical and laboratory examinations were performed in the Clinic of Urology, "St. Marina" University Hospital, Varna during the period January - December, 2015. All patients were histologically verified, either by systemic transrectal ultrasound-guided tru-cut prostate biopsies (10 cores at least), or by transurethral resection of the prostate (TURP), or open prostatectomy.

\section{Laboratory Examinations}

Fasting blood samples were collected only once - at the time of patients' admittance in the Urology Clinic. The serum was separated by centrifugation and all serum samples were frozen and stored at $-80^{\circ} \mathrm{C}$ until analysis.

\section{$25 \mathrm{OHD}$}

Serum 25OHD was assayed by a validated LC-MS/MS method. The vitamin D status was defined as severe deficiency $(25 \mathrm{OHD}<25 \mathrm{nmol} / \mathrm{L})$, deficiency $\quad(25 \mathrm{OHD}<50 \mathrm{nmol} / \mathrm{L})$, sufficiency $(25 \mathrm{OHD}>50 \mathrm{nmol} / \mathrm{L})$, and optimal values $-25 \mathrm{OHD}>75 \mathrm{nmol} / \mathrm{L}$.

\section{Biochemical Parameters}

Serum levels of glucose, creatinine, calcium, and inorganic phosphate were determined on biochemical analyzer ADVIA 1800, using standard clinical laboratory kits.

Standard chemiluminescent immunometric methods on Immulite 2000 Immunoassay System
(Siemens Healthcare Diagnostics, USA) was used for measuring TT and PSA serum levels.

\section{Other Covariates}

Detailed information, regarding patient height, weight, age, and history of the disease was collected by interview at the time of hospitalization. BMI was calculated as weight $(\mathrm{kg}) /$ height $^{2}\left(\mathrm{~m}^{2}\right)$.

\section{Statistics}

GraphPad Prism version 6.00 for Windows (GraphPad Software, La Jolla, California, USA) was used for statistical analysis of continued variables. Student t-test for comparison of means of different parameters was used. The level of significance was set at $\mathrm{p}<0.05$. A non-parametric Spearman correlation analysis was performed to evaluate the associations between serum 25OHD levels and other tested parameters.

The study was approved by the local Ethics Committee, following the guidelines of the Declaration of Helsinki (Protocol No 54/19.05.2016).

\section{RESULTS}

\section{Charactersitics of the Studied BPH Patients}

The characteristics of BPH patients included in the study are presented in Table 1.

The mean serum TT levels of $\mathrm{BPH}$ patients were close to the lower limit of $10.4 \mathrm{nmol} / \mathrm{L}$ for normal TT according to the recommendations of the Endocrine Society.

The mean level of $25 \mathrm{OHD}$ for $\mathrm{BPH}$ patients was close to the lower reference limit of $50 \mathrm{nmol} / \mathrm{L}$ recommended by the US Endocrine Society Guideline (23). Almost half (43.2\%) of all studied BPH patients were vitamin $\mathrm{D}$ deficient $(25 \mathrm{OHD}<50 \mathrm{nmol} / \mathrm{L})$. Among them $8.1 \%$ were with severe vitamin $\mathrm{D}$ deficiency $(25 \mathrm{OHD}<25 \mathrm{nmol} / \mathrm{L})$. The majority of $\mathrm{BPH}$ patients (56.8\%) displayed 25OHD levels higher than $50 \mathrm{nmol} / \mathrm{L}$. Only 6 patients $(16.2 \%)$ had optimal $25 \mathrm{OHD}$ levels above $75 \mathrm{nmol} / \mathrm{L}$.

Overweight and obesity were prevalent in $59.5 \%$ of the studied men. No significant difference between $25 \mathrm{OHD}$ values of overweight and normal weight $\mathrm{BPH}$ patients was established. The other tested laboratory parameters were in the reference range.

Seasonality in $25 \mathrm{OHD}$ and $\mathrm{TT}$

Since the 25OHD levels show considerable seasonality, we stratified the studied population by the 


\begin{tabular}{lcc} 
Parameters & Mean value \pm SD & Reference range \\
Age, years & $67.14 \pm 7.772$ & \\
25OHD, nmol/L & $54.98 \pm 21.93^{*}$ & $\begin{array}{c}\text { Optimal: }>75 \\
\text { Insufficiency: } 50-75 \\
\text { Deficiency: }<50\end{array}$ \\
TT, nmol/L & $10.74 \pm 4.026$ & Normal: $>10.4$ \\
PSA, ng/ml & $4.152 \pm 4.066^{*}$ & $0-4$ \\
Glucose, $\mathrm{mmol} / \mathrm{L}$ & $5.748 \pm 1.335$ & $3.3-5.8$ \\
Creatinine, $\mu \mathrm{mol} / \mathrm{L}$ & $88.65 \pm 19.52$ & $70-120$ \\
Calcium, $\mathrm{mmol} / \mathrm{L}$ & $2.396 \pm 0.1896$ & $2.18-2.58$ \\
Phosphate, $\mathrm{mmol} / \mathrm{L}$ & $1.000 \pm 0.2147$ & $0.80-1.50$ \\
BMI & $26.38 \pm 3.178^{*}$ & Normal $<25$ \\
\hline \hline
\end{tabular}

TT - total testosterone; BMI - body mass index; PSA - prostate specific antigen; $25 \mathrm{OHD}$ - 25-hydroxy vitamin D. ${ }^{*}$ - mean values outside the reference range.

season of blood drawing as follows: cold season (November-May), and warm season (June-October). During the cold period 17 subjects $(48.6 \%)$ were assayed, and $18(51.4 \%)$ - in the warm season. There were significant differences in $25 \mathrm{OHD}$ levels $(\mathrm{p}<0.05)$ between the cold and warm season (Fig.1A). During the warm period the $25 \mathrm{OHD}$ levels were in the range of vitamin D sufficiency $(61.79 \pm 19.99 \mathrm{nmol} / \mathrm{L})$, while during the cold season vitamin D deficiency was de-

A

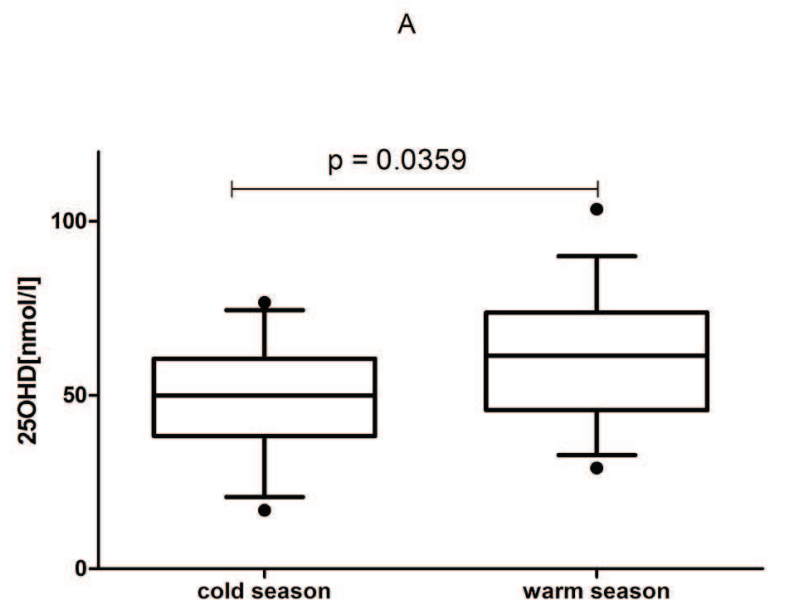

tected $(48.13 \pm 16.68 \mathrm{nmol} / \mathrm{L})$. Similar seasonality was not established for TT (Fig. 1B).

Stratification by PSA, TT and 25OHD Levels

Two-thirds of the BPH patients (62.9\%) were with PSA values below the upper limit of the reference interval of $4 \mathrm{ng} / \mathrm{ml}$. The remaining $37.1 \%$ revealed PSA levels above the reference limit. Patients with abnormal PSA values $(>4 \mathrm{ng} / \mathrm{ml})$ were vitamin $\mathrm{D}$ deficient $(46.12 \pm 6.134 \mathrm{nmol} / \mathrm{L})$. Higher $25 \mathrm{OHD}$

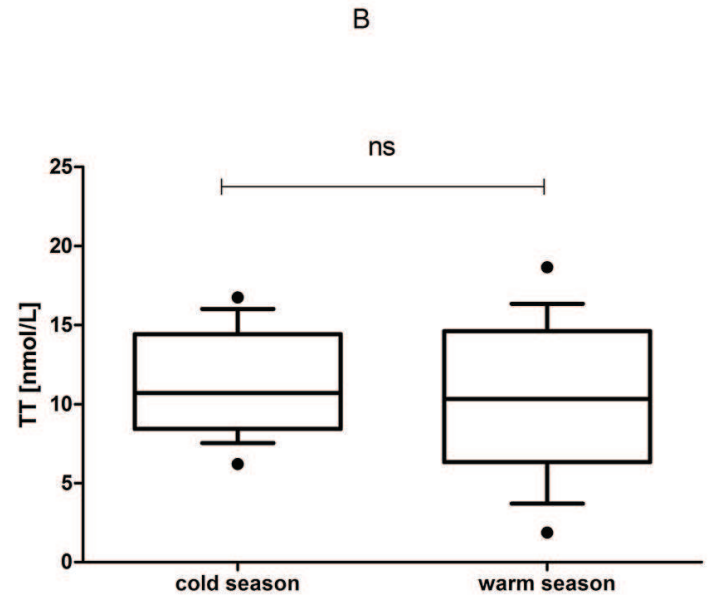

Fig. 1. Seasonal variation of $25 \mathrm{OHD}$ and TT levels

(A) 25OHD levels in warm and cold season

(B) TT levels in warm and cold season

Legend: 25OHD - 25-hydroxy vitamin D; TT - total testosterone; ns - non significant 
Bogdan Roussev, Daniela Gerova, Petar Kosev et al.

levels $(59.21 \pm 3.756 \mathrm{nmol} / \mathrm{l}, \mathrm{p}=0.06)$ were established for the group with PSA below the threshold of $4 \mathrm{ng} /$ $\mathrm{ml}$ (Fig. 2A). For the same PSA groups no differences were found for TT values (Fig. 2B).

A

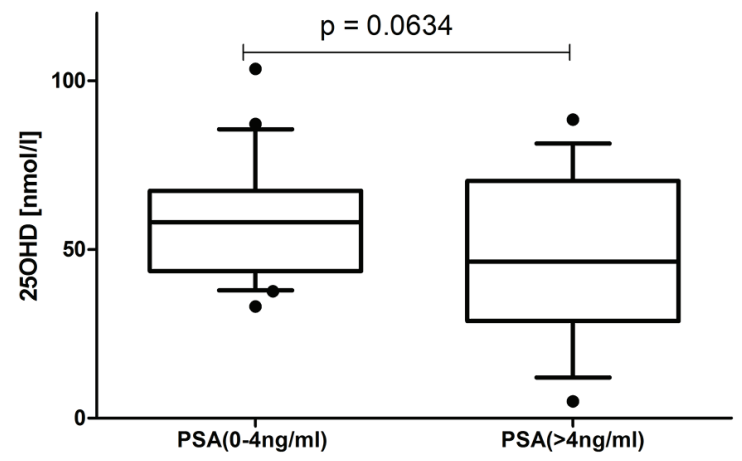

threshold for hypogonadism: $56.81 \pm 19.30 \mathrm{nmol} / \mathrm{L}$ for $\mathrm{TT}<10.4 \mathrm{nmol} / \mathrm{L}$ vs $53.24 \pm 24.57 \mathrm{nmol} / \mathrm{L}$ for $\mathrm{TT}>10.4$ $\mathrm{nmol} / \mathrm{L}$.

The stratification of patients by their 25OHD

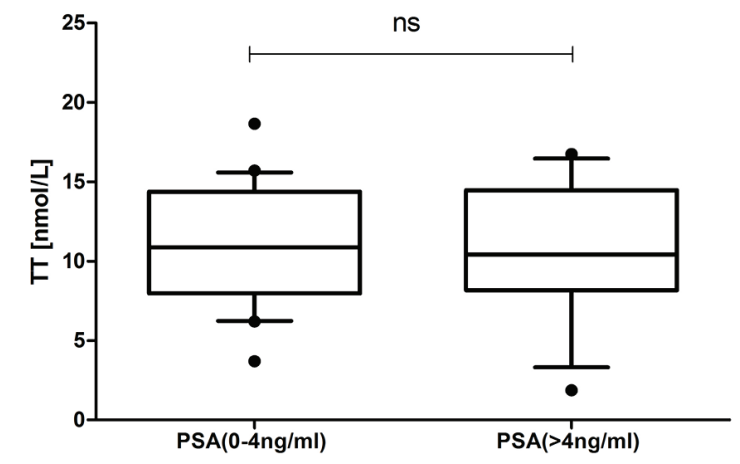

Fig. 2. 25OHD and TT levels in BPH patients stratified by their PSA values

(A) $25 \mathrm{OHD}$ in $\mathrm{BPH}$ patients according to their PSA values

(B) TT levels in BPH patients according to their PSA values

Legend: 25OHD - 25-hydroxy vitamin D; TT - total testosterone; PSA - prostate specific antigen; ns - non significant

A

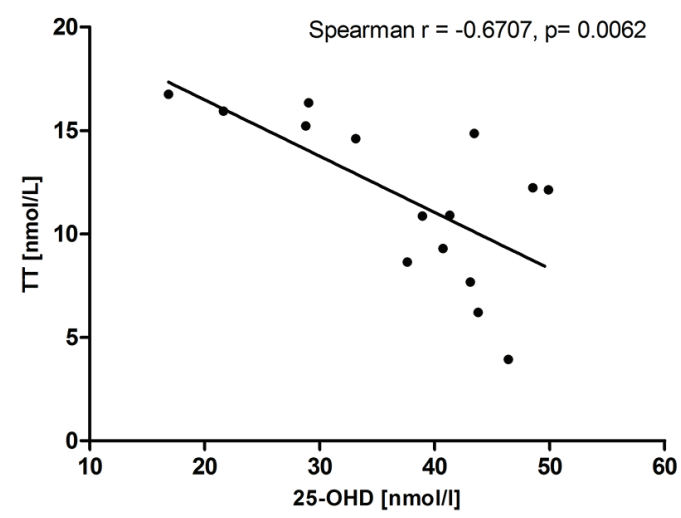

B

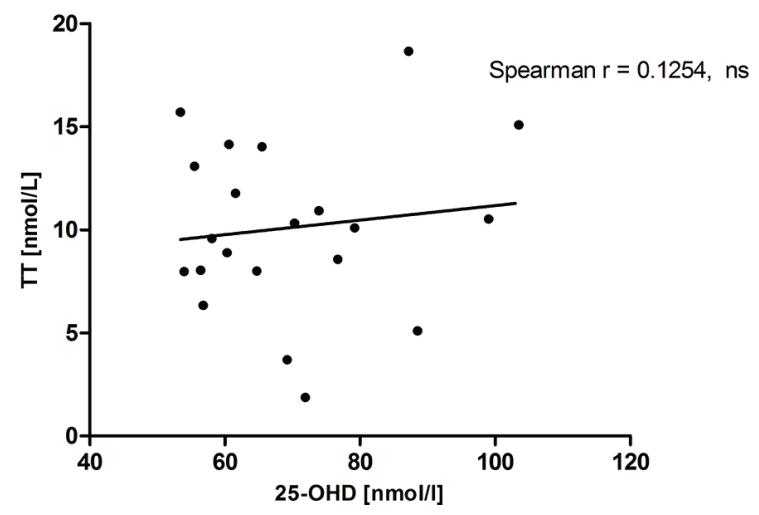

Fig. 3. Association between $25 \mathrm{OHD}$ and TT levels in $\mathrm{BPH}$ patients

(A) BPH patients with $25 \mathrm{OHD}$ below $50 \mathrm{nmol} / \mathrm{L}$

(B) $\mathrm{BPH}$ patients with $25 \mathrm{OHD}$ above $50 \mathrm{nmol} / \mathrm{L}$

Legend: $25 \mathrm{OHD}$ - 25-hydroxy vitamin D; TT - total testosterone

Almost half (51.4\%) of $\mathrm{BPH}$ patients were with TT levels above the threshold for hypogonadism $(10.4 \mathrm{nmol} / \mathrm{L})$. No differences in $25 \mathrm{OHD}$ levels were detected when the patients were divided by the levels below and above the cut-off value for vitamin $D$ deficiency revealed no difference in their average TT concentrations $(11.55 \pm 3.87 \mathrm{nmol} / \mathrm{L}$ vs $10.12 \pm 4.12$ $\mathrm{nmol} / \mathrm{L})$. 
Associations Between 25OHD and TT

A moderate negative correlation was found between 25OHD and TT (Spearman $\mathrm{r}=-0.6707, \mathrm{p}<0.01$ ) only for the vitamin $\mathrm{D}$ deficient group. In case of vitamin D sufficiency, a weak positive trend was detected (Fig. 3 A,B).

No significant differences in anthropometric and biochemical parameters were found when the $\mathrm{BPH}$ patients were stratified by the cut-off for vitamin D deficiency or by the threshold for hypogonadism.

\section{DISCUSSION}

Benign prostate hyperplasia (BPH) is one of the most common conditions affecting men (24). It is a chronic progressive disease, histologically proven in approximately $50 \%$ of men over 50 years, and $90 \%$ of men who are 80 years of age (25). The mechanisms of $\mathrm{BPH}$ are multifactorial and not well understood. It is known that androgens play crucial role in prostate growth and differentiation. The increased prostatic concentration of androgens, or increased androgen responsiveness is considered to result in stromal and glandular cell hyperproliferation (26). One of the most important androgens is testosterone, which is converted in the prostate to dihydrotestosterone (DHT). DHT stimulates glandular epithelial prostate cell growth and is considered as a prime factor for prostate enlargement in later adulthood (2).

In our study $51.4 \%$ of the studied $\mathrm{BPH}$ patients, revealed TT values above the threshold of $10.4 \mathrm{nmol} / \mathrm{L}$ (mean:13.89 $\pm 2.335 \mathrm{nmol} / \mathrm{L})$. The remaining 48.6\% (mean:7.41 $\pm 2.40 \mathrm{nmol} / \mathrm{L}$ ) fell below the limit of $8 \mathrm{nmol} / \mathrm{L}$ for hypogonadism, indicated by the European Association of Urology (EAU) and the European Academy of Andrology (EAA) (27). The $\mathrm{BPH}$ patients in our study exhibited lowest mean values for TT $(10.74 \mathrm{nmol} / \mathrm{L})$, compared to those in other studies $13.9 \mathrm{nmol} / \mathrm{L}$ (28) and $16.75 \mathrm{nmol} / \mathrm{L}$ (4).

Besides androgens, several other factors such as age, inflammation and diet are considered to play role in $\mathrm{BPH}$ (4). The accumulated amount of data reveals that vitamin $\mathrm{D}$ is one of the most potent growth regulatory molecules in prostate. Both epithelial and stromal cells express nuclear vitamin D receptor, which binds the active form of vitamin $\mathrm{D}$ and initiates a signaling cascade resulting in antiproliferation and prostate growth inhibition (29).
There is no consensus on the optimal 25OHD reference ranges. According to the Endocrine Society, vitamin $\mathrm{D}$ deficiency is defined as $25 \mathrm{OHD}$ below the "cut off" $50 \mathrm{nmol} / \mathrm{L}$, and vitamin D insufficiency - as a $25 \mathrm{OHD}$ between $50-75 \mathrm{nmol} / \mathrm{L}$ (23). Many leading authorities believe that health-based reference values are preferable. Accordingly, vitamin D deficiency is defined as $25 \mathrm{OHD}$ below $50.0 \mathrm{nmol} / \mathrm{L}$, insufficiency: $50.0-75.0 \mathrm{nmol} / \mathrm{L}$, sufficiency: 75.0-250.0nmol/L, toxicity: >250.0nmol/L $(30,31)$.

The vitamin D status of our BPH patients can be determined as vitamin $\mathrm{D}$ insufficiency, showing mean 25OHD value close to the lower limit of the range $50.0-75.0 \mathrm{nmol} / \mathrm{L}$. Approximately $40 \%$ of the studied patients were vitamin D deficient (25OHD $<50 \mathrm{nmol} / \mathrm{L}$ ) and only $16.2 \%$ exceeded the optimal limit of $75 \mathrm{nmol} / \mathrm{L}$. Our results indicate more severe vitamin $\mathrm{D}$ insufficiency when compared to the data of Haghshneno et al, reporting average 25OHD values of $64.37 \mathrm{nmol} / \mathrm{L}$, close to the upper reference limit (4). The distribution by $25 \mathrm{OHD}$ levels revealed that $83.8 \%$ of our $\mathrm{BPH}$ patients were below the optimal limit of $75 \mathrm{nmol} / \mathrm{L}$, compared to $69 \%$ in the study of Nimpsch et al. The same study reported vitamin D deficiency only in $24 \%$ of the studied patients, vs $43 \%$ in our study (29). Pitman et al reported similar to our results in a cohort study of urological patients. They found that $52 \%$ of their patients were vitamin D deficient (less than $50 \mathrm{nmol} / \mathrm{L}$ ) (32). Surprisingly, lower median $25 \mathrm{OHD}$ values $(37.37 \mathrm{nmol} / \mathrm{L})$ for the peak season for vitamin $\mathrm{D}$ synthesis were reported by Zhang et al for a cohort of 322 men aged 60 to 75 years from South China. More than $71 \%$ of their studied patients were vitamin D deficient and only $6.6 \%$ fall in the range over $75 \mathrm{nmol} / \mathrm{L}$ (28).

Vitamin D seasonality is well documented and our results are in agreement with reported data for significantly higher 25OHD levels in summer and fall (warm season) vs lower 25OHD values in spring and winter (cold season) $(28,29)$. The data regarding testosterone seasonal variations are scarce and controversial. Our results did not show seasonal changes in TT levels or seasonal relationship between 25OHD and TT. In agreement with our results, many studies have found no seasonal variation in TT or seasonal relationship between $25 \mathrm{OHD}$ and TT $(22,29)$. On the contrary, others have found similar seasonal pattern between 25OHD and TT (19). 
Bogdan Roussev, Daniela Gerova, Petar Kosev et al.

PSA is a glycoprotein secreted by the epithelial cells of the prostate gland. PSA is widely used tumor marker for prostate cancer. In addition to prostate cancer, a number of benign conditions, such as $\mathrm{BPH}$, can cause elevation in PSA. It is estimated that every $19 \%$ decrease in the PSA levels corresponds to a decrease in a prostate volume by $10 \%$ (2). Therefore, most of the studies on $\mathrm{BPH}$ patients examine the association between PSA and prostate volume $(8,32,33)$. The median PSA level $(3.12 \mathrm{ng} / \mathrm{ml})$ of our $\mathrm{BPH}$ patients was close to the upper reference limit of $4 \mathrm{ng} / \mathrm{ml}$. Consistently with our findings Zhang et al and Putra et al reported similar median PSA values for Indonesian $(3.28 \mathrm{ng} / \mathrm{ml})$ and Chinese $(4.81 \mathrm{ng} /$ $\mathrm{ml}) \mathrm{BPH}$ patients $(8,28)$. In our study, $37.1 \%$ of $\mathrm{BPH}$ patients revealed PSA levels above the cut-off limit accompanied with vitamin D deficiency. Putra et al reported relatively higher percentage $(56.35 \%)$ of abnormal PSA for Indonesian BPH patients (8). Although the data concerning the link between PSA and 25OHD levels are very scarce in the literature, Zhang et al established no direct association between serum PSA and 25OHD in patients with and without vitamin D deficiency. They reported strong association between the presence of vitamin $\mathrm{D}$ deficiency and $\mathrm{BPH}$, suggesting that vitamin $\mathrm{D}$ deficiency may be a marker of BPH (28).

Most studies revealed positive association between TT and 25OHD levels in BPH patients $(9,22,29)$. Surprisingly, we found a weak negative association between 25OHD and TT levels for all studied BPH subjects (Spearman $\mathrm{r}=-0.298, \mathrm{p}=0.077$ ). When the patients were stratified into two groups by the cut-off for 25OHD, this negative association becomes stronger and significant (Spearman $r$ $=-0.6707, \mathrm{p}<0.01$ ) for the vitamin $\mathrm{D}$ deficient group. The increase of $25 \mathrm{OHD}$ levels above $50 \mathrm{nmol} / \mathrm{L}$ in the vitamin $\mathrm{D}$ sufficient group results in a weak positive trend for elevation also in TT levels. Our data are consistent with the findings of Jorge et al, 2013 reporting no increase in serum TT after high dose vitamin D supplementation (34). It can be speculated that the relationship between these two steroids, 25OHD and TT, somehow depends on the vitamin D status - deficiency or sufficiency.

\section{CONCLUSION}

Most of the studied BPH patients were vitamin D insufficient, with 25OHD levels below the optimal limit of $75 \mathrm{nmol} / \mathrm{L}$ for manifestation of its antiproliferative effects on prostate gland. Higher $25 \mathrm{OHD} \mathrm{lev-}$ els were associated with lower PSA values indicating a potential favorable effect of $25 \mathrm{OHD}$ on prostate gland.

The contradictory data from mechanistic studies on BPH patients concerning the relationship between 25OHD and TT require further research on their molecular interplay in the prostate gland. Until then, the answer of the question "Is vitamin D associated with testosterone in benign prostate hyperplasia?" will still be pending.

\section{ACKNOWLEDGMENTS}

The study was funded by the Research Fund "Science" at the Medical University of Varna, Bulgaria.

\section{REFERENCES}

1. Yalçınkaya S, Eren E, Eroglu M, Aydin O, Yilmaz N. Deficiency of vitamin D and elevated aldosterone in prostate hyperplasia. Adv Clin Exp Med. 2014;23(3):441-6.

2. Praveen R. Benign prostatic hyperplasia: updated review. Int. Res. J. Pharm. 2013;4 (3):45-51.

3. Espinosa G, Esposito R, Kazzazi A, Djavan B. Vitamin $\mathrm{D}$ and benign prostatic hyperplasia -- a review. Can J Urol. 2013;20(4):6820-5.

4. Haghsheno MA, Mellström D, Behre CJ, Damber JE, Johansson H, Karlsson M, et al. Low 25-OH vitamin $\mathrm{D}$ is associated with benign prostatic hyperplasia. J Urol. 2013;190(2):608-14.

5. Vuolo L, Di Somma C, Faggiano A, Colao A. Vitamin D and Cancer Front Endocrinol (Lausanne). 2012; 3: 58 .

6. Kristal AR, Arnold KB, Schenk JM, Neuhouser MJ, Goodman P, Penson DF, et al. Dietary patterns, supplement use, and the risk of symptomatic benign prostatic hyperplasia: results from the Prostate Cancer Prevention Trial. Am J Epidemiol 2008;167: 925.

7. Usoro AJ, Obot AS, Ekaidem IS, Akaiso OE, Udoh AE, Akinloye O. Serum Testosterone, 17 $\beta$-Estradiol and PSA Levels in Subjects with Prostate Disorders. Indian J Clin Biochem. 2015;30(1):59-65. 
8. Putra IB, Hamid AR, Mochtar CA, Umbas R. Relationship of age, prostate-specific antigen, and prostate volume in Indonesian men with benign prostatic hyperplasia. Prostate Int. 2016;4(2):43-8.

9. Pilz S, Frisch S, Koertke H, Kuhn J, Dreier J, Obermayer-Pietsch B, et al. Effect of vitamin D supplementation on testosterone levels in men. Horm Metab Res. 2011;43(3):223-5.

10. Chul YU, Jin KY, Byung YY. Association between serum 25-hydroxyvitamin D levels and total testosterone levels in Korean adult men. Bone Abstracts 2016;5:276.

11. Jorde R, Grimnes G, Hutchinson MS, Kjærgaard M, Kamycheva E, Svartberg J. Supplementation with vitamin $\mathrm{D}$ does not increase serum testosterone levels in healthy males. Horm Metab Res. 2013;45(9):675-81.

12. Galunska B, Gerova D, Kosev P, Anakievski D, Hinev A. Serum 25-hydroxy vitamin D levels in Bulgarian patients with prostate cancer: a pilot study. Clin Lab. 2015;61(34):329-35.

13. Roth HJ, Schmidt-Gayk H, Weber H, Niederau C. Accuracy and clinical implications of seven 25-hydroxyvitamin D methods compared with liquid chromatography-tandem mass spectrometry as a reference. Ann ClinBiochem. 2008;45(2):153-9.

14. Holick MF. Vitamin D deficiency. N Engl J Med. 2007;357:266-281.

15. Wagner CL, Greer FR. Prevention of rickets and vitamin D deficiency in infants, children, and adolescents. Pediatrics. 2008;122:1142-1152.

16. Hollis BW. Circulating 25-hydroxyvitamin D levels indicative of vitamin D sufficiency: implications for establishing a new effective dietary intake recommendation for vitamin D. J Nutr. 2005;135:317-322.

17. Macdonald HM. Contributions of sunlight and diet to vitamin D status. Calcif Tissue Int. 2013;92(2):163-76.

18. Vuistiner P, Rousson V, Henry H, Lescuyer P, Boulat O, Gaspoz JM. Population-Based Model to Consider the Effect of Seasonal Variation on Serum 25OHD and Vitamin D Status. Biomed Res Int. 2015;2015:168-189.

19. Wehr E, Pilz S, Boehm BO, März W, Obermayer-Pietsch B. Association of vitamin D status with serum androgen levels in men. Clin Endocrinol (Oxf). 2010;73(2):243-8.
20. Andersson AM, Carlsen E, Petersen JH, Skakkebaek NE. Variation in levels of serum inhibin B, testosterone, estradiol, luteinizing hormone, follicle-stimulating hormone, and sex hormone-binding globulin in monthly samples from healthy men during a 17-month period: possible effects of seasons. J Clin Endocrinol Metab. 2003;88(2):932-7.

21. Svartberg J, Jorde R, Sundsfjord J, Bønaa KH, Barrett-Connor E. Seasonal variation of testosterone and waist to hip ratio in men: the Troms $\varnothing$ study. J Clin Endocrinol Metab. 2003;88(7):3099-104.

22. Tak YJ, Lee JG, Kim YJ, Park NC, Kim SS, Lee S. Serum 25-hydroxyvitamin D levels and testosterone deficiency in middle-aged Korean men: a cross-sectional study. Asian J Androl. 2015;17(2):324-8.

23. Holick M, Binkley N. Bischoff-Ferrari H, Gordon CM, Hanley DA, Heaney RP, et al. Evaluation, Treatment, and Prevention of Vitamin D Deficiency: an Endocrine Society Clinical Practice Guideline J Clin Endocrinol Metab 2011; 96(7):1911-1930.

24. Crescioli C, Villari D, Forti G, Ferruzzi P, Petrone L, Vannelli GB, et al. Des (1-3) IGF-I-stimulated growth of human stromal BPH cells is inhibited by a vitamin D3 analogue. Mol Cell Endocrinol. 2002;198(1-2):69-75.

25. Carson C 3rd, Rittmaster R. The role of dihydrotestosterone in benign prostatic hyperplasia. Urology. 2003;61(4 Suppl 1):2-7.

26. Crescioli C, Maggie M, Vannelli GB, Luconi M, Salerno R, Barni T, et al. Effect of a vitamin D3 analogue on keratinocyte growth factor-induced cell proliferation in benign prostate hyperplasia. J Clin Endocrinol Metab. 2000;85(7):2576-83.

27. Dandona P, Rosenberg MT. A practical guide to male hypogonadism in the primary care setting Int J Clin Pract. 2010;64(6):682-696.

28. Zhang W, Zheng X, Wang Y, Xiao H. Vitamin D Deficiency as a Potential Marker of Benign Prostatic Hyperplasia. Urology, 2016;S0090-4295(16)30308-9.

29. Nimptsch K, Platz EA, Willett WC, Giovannucci E. Association between plasma 25-OH vitamin $\mathrm{D}$ and testosterone levels in men. Clin Endocrinol (Oxf). 2012;77(1):106-12.

30. Vaishya R. Vijay V, Agarwal AK, Jahangir J. Resurgence of vitamin D: Old wine in new bottle. J Clin Orthop Trauma. 2015;6(3):173-83. 
Bogdan Roussev, Daniela Gerova, Petar Kosev et al.

31. Vieth R. Why the minimum desirable serum 25-hydroxyvitamin D level should be $75 \mathrm{nmol} / \mathrm{L}$ (30 ng/ml). Best Pract Res Clin Endocrinol Metab. 2011;25(4):681-91.

32. Park DS, Hong JY, Hong YK, Lee SR, Hwang JH, Kang MH, et al. Correlation between serum prostate specific antigen level and prostate volume in a community-based cohort: large-scale screening of 35,223 Korean men. Urology 2013;82:1394-1399.

33. Mochtar CA, Kiemeney LA, van Riemsdijk MM, Barnett GS, Laguna MP, Debruyne FM, et al. Prostate-specific antigen as an estimator of prostate volume in the management of patients with symptomatic benign prostatic hyperplasia. Eur Urol 2003;44:695-700.

34. Jorde R, Grimnes G, Hutchinson MS, Kjærgaard M, Kamycheva E, Svartberg J. Supplementation with vitamin $\mathrm{D}$ does not increase serum testosterone levels in healthy males. Horm Metab Res. 2013;45(9):675-81.

35. Pitman MS, Cheetham PJ, Hruby GW, Katz AE. Vitamin D deficiency in the urological population: a single center analysis. J Urol. 2011;186:1395-1399.

36. Roth HJ, Schmidt-Gayk H, Weber H, Niederau C. Accuracy and clinical implications of seven 25-hydroxyvitamin D methods compared with liquid chromatography-tandem mass spectrometry as a reference. Ann Clin Biochem. 2008;45(2):153-9.

37. Maguire O, Pollock C, Martin P, Owen A, Smyth T, Doherty D, et al. Regulation of CYP3A4 and CYP3A5 expression and modulation of „intracrine“ metabolism of androgens in prostate cells by liganded vitamin D receptor. Mol Cell Endocrinol. 2012;364(1-2):54-64.

38. Colli E, Rigatti P, Montorsi F, Artibani W, Petta S, Mondaini N, et al. BXL628, a novel vitamin D3 analog arrests prostate growth in patients with benign prostatic hyperplasia: a randomized clinical trial. Eur Urol. 2006;49(1):82-6.

39. Kim SK, Seok H, Park HJ, Jeon HS, Kang SW, Lee $\mathrm{BC}$, et al. Inhibitory effect of curcumin on testosterone induced benign prostatic hyperplasia rat model. BMC Complement Altern Med. 2015;15:380.

40. Lee DM, Tajar A, Pye SR, Boonen S, Vanderschueren D, Bouillon R, et al. Association of hypogonadism with vitamin D status: the European Male Ageing Study European Journal of Endocrinology 2012;166 77-85.
41. Kennel KA, Drake MT, Hurley DL. Vitamin D Deficiency in Adults: When to Test and How to Treat. Clin Proc. 2010;85(8):752-758. 